\title{
Efficacy of Calotropics procera Leaf Extract and Dyclobos against Ecto-Parasites (Fleas) on Sheep
}

\author{
Muhammed $M M^{1}$, Ibrahim IAA ${ }^{2 *}$, Chindo $\mathrm{M}^{3}$ and Musa $\mathrm{H}^{4}$ \\ ${ }^{1}$ Department of Animal Science, College of Agriculture, Lafia, Nasarawa State, Nigeria \\ ${ }^{2}$ Department of Science Laboratory Technology, School of Science and Technology, Abubakar Tatari Ali Polytechnic Bauchi, Nigeria \\ ${ }^{3}$ Department of Science laboratory Technology, School of Science and Technology, Federal Polytechnic, Nasarawa, Nigeria \\ ${ }^{4}$ Deapartment of Microbiology, Faculty of Science, Bauchi State University
}

*Corresponding Author: Ibrahim IAA. Department of Science Laboratory Technology, School of Science and Technology, Abubakar Tatari Ali Polytechnic Bauchi, Nigeria, Tel: +2348155627750; Email: iliyasuibrahim@gmail.com

Received date: December 30, 2016; Accepted date: January 31, 2017; Published date: February 07, 2017

Copyright: (c) 2017 Muhammed MM, et al. This is an open-access article distributed under the terms of the Creative Commons Attribution License, which permits unrestricted use, distribution, and reproduction in any medium, provided the original author and source are credited.

Citation: Muhammed MM, Ibrahim IAA, Chindo M, Musa H. Efficacy of Calotropics procera Leaf Extract and Dyclobos Against Ecto-Parasites (Fleas) on Sheep. Eur J Exp Bio. 2017, 7:3.

\section{Abstract}

Research was carried out to investigate the Efficacy of Calotropics procera Leaf Extract and Dyclobos against ectoparasites (fleas) on sheep. Effect of Calotropis procera Leaf Extract and Dyclobos on weight, Packed Cell Volume (PCV) and repellence were studied on sheep. A total number of 18 sheep were examined for the presence of fleas by physical examination and were divided into three equal groups as; 'D' (infested control group), 'E' (treated with Dyclobos), F (treated with Calotropis procera), on day 14 of post treatment it was discovered that the PCV level and body weight of treated group ( $E$ and $F$ ) increased significantly and relative infestation decreased, all the sheep after dipping in Dyclobos diluted water and Calotropis procera spray remained healthy, no adverse effect on sheep was observed. On the other hand, the PCV and body weight of control group decreased on day 14 and the number of fleas per surface area of the body increased.

Keywords: Packed cell volume; Ecto parastes infestation; Ethylene diamine tetraacetic acid

\section{Introduction}

Calotropis procera (known by the common names apple of sodom, Sodom apple, mudar or oshe" is a species of flowering plant in the dogbone family. Apocynaceac that is native to North Africa, Tropical Africa, Western Asia, South Asia and Indo China [1]. It is commonly known as apple of Sodom a name derived from the Hebrew tapuah Sodom [2]. The green globes are hallow but the flesh contain a toxic milky sap that is extremely bitter and turns into a gluey coating resistant to soap [2].

A large quantity of latex can be easily collected from its green parts. The abundance of latex in the green parts of the plant indicates that it is probably produced and accumulated as a define strategy against organisms such as virus, fungi, insects and larger herbivores [3].

Thus, it has been found to be used by indigenous people to successfully combat some coetaneous fungal infection [3]. Different plant parts as well as latex Calotropis procera have been reported to have emetic, purgative and anthelmintic effect in traditional medicine [4] Calotropis procera flowers are mostly used as an anthelmintic in small ruminants in the form of decoction and small ruminants in the form of decoction and I or crude powder mixed with jiggery and administered as physic drench/balls [5].

Fleas are small, wingless insects that feed on the blood of animals and people. During their life cyde fleas pass through four stages; egg, larva, pupa and adult. Although they can jump, adult fleas do not usually travel long distances without a host Fleas prefer to wait and jump onto a passing animal. Once aboard, they remain until they are dislodged or groomed from the animal. Without a host, adult fleas live only a few days to 2 weeks. On short-haired cats and dogs, fleas survive an average of 8 days; they live longer on long haired animals [6].

The female flea begins laying eggs within 2 days of her first blood meal. Four to 9 days later she produces an average of 27 eggs per day. Consuming about 15 times her body weight in blood daily. Much of this blood is excreted as partially digested feaces. Flea feaces are a fine, reddish-black dust seen in pot for bedding. Flea larvae feed on adult flea excrement. Without it, they cannot survive, although they also may feed on organic matter such as food participles, dead skin or feathers. Larvae develop in 5 to 11 days [7].

Fleas are known to be a harmful insect in farm animals which feed on blood and causes some serious diseases in farm animals. The exclusive use of chemical insecticides put a great strain on the national economy [8]. The frequent use of chemical insecticides for several decades has disrupted biological control system by natural enemies and lead to outbreaks of insect pests. 
Widespread development of resistance understanding effect on non-target organisms, environmental and human health concerns [8].

Plant may provide potential alternatives to currently used insect control agents because they constitute a rich source or bioactive chemicals [9]. Since these are often active against a limited number or species including specific target insects, are often biodegradable to non-toxic products and are potentially suitable for use in integrated pest management and they could lead to the development of new classes of safer insects. Control agents. Much effect has therefore, been focused on plant derived materials for potentially useful products as commercial insect control agents.

Calotropis procera (Aselepia daceae), with the common name Usher, is a xerophytic erect shrub, growing widely throughout the tropic of Africa and Asia and it is grown abundantly in arid and semi-arid regions without irrigation, fertilizer application, pesticides or other agronomic practices. This plant has been widely used in the Sudanese medicinal system [10]. The latex of the plant was reported having potential anti-inflammatory, ant diarrheal, analgesic, antipyretic and schizonticidal activities $[11,12]$. Objectives of the study therefore, is to study the efficacy of Calotropis procera leaf extract on repellence of fleas; to investigate the effect of Calotropis procera leaf extract on weight gain and to examine the effect of Calotropis procera leaf extract on blood count Packed Cell Volume (PCV).

\section{Materials and Method}

\section{Experimental site}

The study was conducted at the small ruminant animal farm of the College of Agriculture, Bauchi, Nigeria to investigate the efficacy of Calotropis Procera leaf extract on treatment of ectoparasite (fleas) on farm animals (sheep).

\section{Treatments and experimental design}

The experiment consisted of three treatments. A total of 60 sheep were used, 20 sheep per treatment. control, conventional drug and Calotropis Procera leaf extract. The treatments were randomized and applied in a complete randomized design with six replications.

\section{Calotropis procera plant extraction}

The latest leaves of Calotropis procera were collected from the forestry department and slashed into small sizes, and air dried exposed to sunlight for many days, until it has become completely dry, the dried leaves were manually smashed and sift to obtained soft powder. $0.5 \mathrm{~kg}$ of powder were mixed with 1 liter of clean water and boiled.

\section{Application of treatments}

Water was used to dissolve most of the powdered drugs for topical application. This allows for uniform application of the drug on the body surface of the animal by way of using sprayers. A pair of rain boots, masks, syringe and needle, weighing scale, ear tags, antibiotic, measuring cylinder, detergents, Calotropis procera leaf extract solution, organophosphate dyclobos was used during the application of the treatment.

\section{Data Collection}

\section{Weight gain}

The weight of the animal was determined with a weighing scale at the beginning of the experiment. The weight of the assistant was taken as an initial weight then the weight of assistant plus that of the animal was considered as the final weight. So, the actual weight of the animal was obtained by subtracting the initial weight from the final weight. The obtainable values were recorded as the weight of the animal in kilogram (kg).

\section{Blood count or packed cell volumes (PCV)}

The blood count or Packed Cell Volumes (PCV) was determined by taking little amount of blood sample from the jugular vein of each animal and transferred into the blood sample bottle that contain material that prevent clotting of the blood (EDTA). $2 \mathrm{ml}$ of blood was placed in the haematocrit centrifuge, at 3.000 revolutions per minute for 5 minutes. The result was read using micro-haemotocrit reader in percentage (\%). Infestation was determined by physical examination of the body surface area of the animal checking for either severe form (dense population of flees) or mild forms of infestation (sparse population of fleas).

\section{Results and Discussion}

The effect of calotropis extract and dyclobos on body weight of sheep (Table 1 ) indicated that the average initial body weight of group ' 0 ' (control) on day 1 and 14 day were $33.0 \mathrm{~kg}$ and 32.4 $\mathrm{kg}$ respectively. So, body weight of sheep in control (group D) decreased on day 14 of treatment. On the other hand, the body weight was increased significantly in groups ( $E$ and $F$ ) to $33.4 \mathrm{~kg}$ and $33.8 \mathrm{~kg}$ (group B); (E) from $34.1 \mathrm{~kg}$ to $34.7 \mathrm{~kg}$ in day 1 and 14 respectively. This is in agreement with the findings of [13] who reported that the parasite infection is dramatically reduced mainly due to the anti feedant effect of the plant extract and body weight increased suddenly.

Table 1 Effect of calotropis extract and dyclobos on body weight $\mathrm{kg}$ of sheep.

\begin{tabular}{|l|l|l|l|l|}
\hline Group & Treatment & Day 1 & Day 14 & Change \\
\hline D & Control & 33.0 & 32.4 & -1.4 \\
\hline E & C. procera & 33.4 & 33.8 & 0.4 \\
\hline F & Dyclobos & 34.1 & 34.7 & 0.4 \\
\hline
\end{tabular}

\section{Data Analysis}

One-way analysis of variance (ANOVA): The $P$ value is 0.0032 , considered very significant. Variation among column means is significantly greater than expected by chance. Tukey-Kramer 
Multiple Comparisons Test of the value of $q$ is greater than 3.674 then the $P$ value is less than 0.05 .

The effect of $C$. procera leaf extract and dyclobos on PCV of sheep (Table 2) indicated that initial average of group 0 were $34.2 \%$, the average value was decreased to $33.0 \%$ on day 14 th of post treatment. On the other hand the PCV value was increased in all treated groups ( $E$ and $F$ ) initially $33.00 \%$ and $35.5 \%$ to extent of $34.5 \%, 36.5 \%$ respectively. This is in agreement with the finding of [14] reported that the active ingredient does not penetrate the skin but dissolve into the skin oils giving long time protection and increased in PCV so observed due to the repellence of blood sucking parasite.

Table 2 Effect of $C$. procera extract and Deyclobos on Packed Cell Volumes (PCV) \%.

\begin{tabular}{|l|l|l|l|l|}
\hline Group & Treatment & Day 1 & Day 14 & Change \\
\hline D & Control & 34.2 & 33 & -1.2 \\
\hline E & C. procera & 33.0 & 34.5 & 1.5 \\
\hline F & Dyclobos & 35.5 & 36.5 & 1.0 \\
\hline
\end{tabular}

The relative infestation increased in group 0 on day 14 from $55.1 \%$ to $72.5 \%$ (Table 3 ) and decreased in treated groups ( $E$ and F) initially from $55.8 \%, 55.1 \%$ to $9.5 \%, 5.3 \%$ respectively; the heir coat become smooth and shiny, this is agreement with the finding of [13] who reported that the parasite infestation is dramatically reduced mainly due to the anti-feedant effect of plant extract.

Table 3 Effect of Calotropis procera on repellences.

\begin{tabular}{|l|l|l|l|l|}
\hline Group & Treatment & Day 1 & Day 14 & Change \\
\hline D & Control & 34.2 & 72.5 & 17.4 \\
\hline E & C. procera & 55.8 & 9.5 & -46.3 \\
\hline F & Dyclobos & 55.1 & 5.3 & -49.8 \\
\hline
\end{tabular}

\section{Conclusion}

From the foregoing it can be deduced that Calotropis procera leave extract has a notable efficacy against flea infestation on sheep.

Calotropis procera leaves could therefore be used as an alternative to any other conventional drug against ecto-parasite; it is naturally available and cheaper. However, prolong use of conventional drug in high dose might accompanied by toxic effect on the host life.

\section{Reference}

1. Babalola JO, Overah LC, Adesola BO, Oninla VO, Olatunde A (2013) Kinetic, Equilibrium and thermodynamic studies on the biosorption of $\mathrm{Cd}$ (II) from aqueous solutions by the leaf biomass of Calotropis procera-'Sodom apple'. J Appl Sci Environ Manage 15: 607-615.

2. Shahat MA, Shihata A (2012) Evaluation of the toxicological effects manifested after long term administration of aqueous Calotropis procera plant extract in male and female rabbits. Egyptian Journal of Hospital Medicine 47: 291-300.

3. Qasem JR (2011) Aqueous extract effects of sorne common weed species against certain plant pathogenic fungi. Revue Marocaine des Sciences Agronomiques et Vétérinaires 16: 11-19.

4. Donkin RA (2013) Manna: an historical geography. Biogeographica.

5. Schmelzer GH, Gurib-Fakim (2013) Medicinal plants. Prota 2: 384 .

6. Begum N, Sharma B, Pandey RS (2013) Caloptropis procera and Annona squamosa: Potential alternatives to chemical pesticides. Br J Appl Sci Technol 3: 254-267.

7. Huang D, Engel MS, Cai C, Wu H, Nel A (2012) Diverse transitional giant fleas from the Mesozoic era of China. Nature 483: 201-204.

8. Stewart A (2011) Wicked Bugs: The Louse that Conquered Napoleon's Army \& Other Diabolical Insects. Algonquin Books.

9. Jundt $T$ (2014) Greening the Red, White, and Blue: The Bomb, Big Business, and Consumer Resistance in Postwar America. Oxford University Press 20: 306.

10. Pagano MC, Dhar PP (2015) Fungal pigments: An overview. Fungal Biomolecules: Sources, Applications and Recent Developments. Microbiology \& Virology 13:173.

11. Ayoub SMH, Kingston DGJ (1981) Screening of plant used in Sudan folk medicine for anticancer activity. Fitoterapea 52: 281-284.

12. Upadhyay RK (2014) Ethnomedicinal, pharmaceutical and pesticidal uses of Calotropis procera (Aiton) (Family: Asclepiadaceae). International Journal of Green Pharmacy 8: 135 .

13. Wadsworth FH (1974) Trees of Puerto Rico and the Virgin Island Vol. 2. Agriculture Handbook 449. U.S. Department of Agriculture, Washington, D.C. S.P. University.

14. Abdulrahman AA, Badar $M$ (1989) Sudanese experience in integrated pest management of cotton insecticide applied. International Journal of Tropical Insect Science 10: 787-794. 